\title{
Does Entry Business Regulation Deter FDI? Evidence from Dynamic Estimators
}

\author{
KYRIAKOS EMMANOUILIDIS*, \\ University of Macedonia, Thessaloniki, Greece \\ CHRISTOS KARPETIS ${ }^{\mathrm{b}}$ \\ University of Macedonia, Thessaloniki, Greece.
}

\begin{abstract}
The present paper aims to examine the effects of entry business regulation on the Foreign Direct Investment (FDI) inflows (net amount) of 185 countries covering a period from 2004 to 2017. For that reason, we estimate a dynamic panel FDI specification, which additionally checks for macroeconomic and institutional factors, using Fixed Effects, Bootstrap Fixed Effects and GMM estimators. Overall, the empirical findings reveal, a negative and statistically significant association between entry regulation and FDI. This suggests that bureaucratic burdens concerning entry regulation can exert adverse effects on the inflow of FDI. Furthermore, when the full sample is separated into different income groups, our findings still indicate evidence of significance, which, however, arises only in the countries of Low and Middle-income.
\end{abstract}

Keywords: Entry Regulation, FDI, Panel Data

JEL classification: C32, F21, L51

\section{Introduction}

Over the last few years, countries increasingly realize the importance of FDI inflows as a vehicle of boosting countries' income since much of the empirical literature suggests that inward FDI is associated with higher income (Adams, 2009; Basu and Guariglia, 2007; Tiwari and Mutascu, 2011; Zhang, 2001). Some of the economic benefits of inward FDI may include job creation, technological, management and marketing advancements as well as the inflow of foreign capital and exchange (Alfaro, 2003; Alfaro et al., 2010; Busse and Groizard, 2008; Crespo and Fontoura, 2007).

\footnotetext{
* Corresponding author, Department of Balkan, Slavic \& Oriental Studies,. E-mail address: kemmanouil@uom.edu.gr

(C) 2019 Kyriakos Emmanouilidis and Christos Karpetis. Licensed under the Creative Commons Attribution - Noncommercial 3.0 Licence (http://creativecommons.org/licenses/bync/3.0/. Available at http: //rofea.org.
} 
Given the possible positive effects of FDI on income, governments of both developed and developing countries take initiatives of implementing various policies that can lead to higher FDI attraction. Despite the fact that there is no general agreement on the factors affecting FDI attractiveness, the importance of business climate is gaining ground in recent years. Although the motivation of reforming the business environment is not limited to FDI attraction, it is a fact that 119 countries implemented at least one regulatory reform between 2016 and 2017 in order to make easier the creation and operation of businesses (World Bank, Doing Business report, 2018).

An aspect of the regulatory environment with a historically high number of reforms is related to entry regulation. This aspect of the business climate represents the ease with which an entrepreneur can enter a specific market. However, the ease of entry of a business into a specific market varies from country to country depending on the legal and institutional framework of each country. In fact, some countries impose significant entry barriers intentionally to fulfill certain objectives. According to public interest theory (Pigou, 1938), the control of new entrants in markets through regulation ensures the compliance of the candidate entrants with a set of minimum requirements. These requirements are capable of securing the quality of the provided goods and services as well as promoting consumers' benefit in general. Contrary to this view, the public choice theory (Posner, 1971; Stigler, 1971; Peltzman, 1976) considers entry regulation as socially inefficient and as a barrier to new entrants that is imposed by the government for the benefit either of politicians and bureaucrats or the domestic industry.

In general, the business entry environment refers to the set of restrictions, costs, and procedures that are imposed on the prospective investors before the legal operation of a company. However, the lack of sufficient dataset concerning countries' business regulatory environment was for a long time the main obstacle for investigating the effects of entry regulation on various aspects of the economy. Djankov et al. (2002) contributed to the literature by providing a methodology on recording entry regulation. This methodology was used to construct a cross-national dataset consisted of the official required procedures, time and costs prior to a business operation. Overall, their findings suggested that heavier entry barriers are associated with higher corruption and unofficial economy. Since then, a growing empirical literature investigated the effects of entry regulation on a wide range of topics such as corruption (Svensson, 2005; Treisman, 2007), productivity (Alesina et al., 2005; Barseghyan, 2008) and entrepreneurship (Klapper et al, 2006; Klapper and Love, 2010; Rin et al., 2011; Kaplan et al., 2011; Branstetter et al., 2013).

Overall, the literature suggests that excessive entry regulation can become a significant obstacle to entrepreneurship and the creation of new firms, while it can be associated with lower employment rates and productivity as well as higher corruption. For example, Klapper and Love (2010) found that reduced entry regulation exerts a positive and significant impact 


\section{EMMANOUILIDIS AND KARPETIS Entry Regulation and FDI}

on registration of new business. Kaplan et al. (2011), who examined the effects of a program that reduced firm registration procedures in Mexico, found that the number of business startups increased by $5 \%$ per month after the implementation of the program. Similarly, according to Branstetter et al. (2013) the impact of regulatory reforms that reduced the costs of entry in Portugal resulted in increased employment and business formation. In addition, Barseghyan (2008) found that higher entry costs significantly limit output per worker because of reduction in total factor productivity whereas Svensson (2005) showed that more corrupted countries tend to regulate more the entrance of new businesses into their markets.

Apart from the issues discussed above, another matter that has sparked researchers' interest over the last few years is the impact of entry regulation on the inflow of FDI. An early attempt in this direction was made by Gastanaga et al. (1998), who showed using the bureaucratic delay index, a sub-index of the Business Environmental Risk Intelligence index, the relevance of bureaucratic delay as a determinant of FDI inflows. Another study that addressed the role of administrative barriers in forming FDI is the one of Morisset and Neso (2002). This study extended Djankov's et al. (2002) dataset by including some additional regulatory procedures concerning imports and exports, land access, site development and main utility service connections. Their findings suggested that a $10 \%$ reduction of the administrative costs would increase FDI by $1.2 \%$.

More recent empirical applications with relevance to our paper exploited the World Bank's Ease of Doing Business indicator ${ }^{1}$ to examine the association between FDI inflows and countries' regulatory environment. In general, empirical results regarding the association between the entry regulatory environment, as expressed from the Starting a Business index, and inward FDI, do not lead to a consensus concerning the significance of the impact. On the one hand, some studies suggest that entry business regulation can play a critical role in determining the level of inward FDI. Those studies assert that the reduction of the time, costs and procedures before the operation of a company lead to higher FDI inflows (Bayraktar, 2013; Olival, 2012; Shahadan et al., 2014; Vogiatzoglou, 2016). On the other hand, a second group of researchers found that improvements into the Starting a Business index do not necessarily lead to higher FDI inflows, as an insignificant relationship between the two variables was revealed (Corcoran and Gillandres, 2015; Jayasuriya, 2011; Jovanovic and Jovanovic, 2015; Hossain et al., 2018; Morris and Azis, 2011).

Thus, the extent to which barriers to business entry influence the decision of foreign investors is still an open question for policymakers who increasingly realize the importance of business climate as a tool through which they can achieve higher economic performance. The

\footnotetext{
${ }^{1}$ The Ease of Doing Business index is a composite index that entails information about countries' regulatory environment and consists of the following sub-indices: 1) Starting a Business, 2) Dealing with construction permits, 3) Getting electricity, 4) Registering property, 5) Getting credit, 6) Protecting Investors, 7) Paying taxes, 8) Trading across borders, 9) Enforcing contracts, 10) Resolving insolvency.
} 
objective of this research is, therefore, to contribute to the understanding of the relationship between entry barriers and inward FDI. In the effort to fulfill this objective, we extend prior literature by providing empirical evidence from 185 countries over the period from 2004 to 2017. In particular, we estimate a dynamic panel FDI specification since the availability of the data concerning their time span enables us to conduct a dynamic analysis in order to take into account the possibility of persistence of FDI.

Although the present paper has great similarities with above-mentioned studies of the relative literature, it differs in several respects. Contrary to prior works, the estimation of the dynamic panel model relies on various estimators including Fixed-effects (FE), bootstrapbased bias-corrected FE, first-difference and system GMM. Adopting different methodologies allows us to enhance the robustness of the results as well as to make comparisons between different estimation methods. Additionally, time-period effects are included in the model estimation as fixed parameters in the context of year dummies. The introduction of the year dummies serves the investigation of the impact of time-specific effects on FDI that are unobservable and cannot be included in the regression. This could be justified given the various exogenous events that could affect the level of FDI such as the economic recession of 2008, improvements in the business climate, economic reforms, etc. Finally, given the heterogeneity within the full sample, the impact of barriers to entry on FDI is disaggregated according to different income groups. This analysis will help us investigate how the strength of the relationship between Entry barriers and FDI varies among different income groups.

The remaining part of the paper is organized as follows. Section 2 provides a description of the employed data and presents the panel model specification. Section 3 describes the various employed empirical methods. Section 4 illustrates the results of the analysis, whereas section 5 takes into consideration the possibility of income heterogeneity within the sample. Finally, the last section draws some interesting conclusions and provides some recommendations for future research.

\section{Data and Empirical Model}

Provided that the aim of the present paper is to uncover the association between entry barriers and FDI inflows (deflated FDI per capita), it is initially necessary to define a variable that could be used as a measure for the barriers to entry. For that reason, we utilize the Starting $a$ Business index, which represents the official required procedures, costs and time before the legal operation of a company in economy's largest business city ${ }^{2}$. These data correspond to the distance to frontier score of each country according to which the performance of an economy ranges from 0 to 100, for the lowest and the best performance, respectively. Hence,

\footnotetext{
2 For further details about the Starting a Business methodology see at: http://www.doingbusiness.org/methodology/starting-a-business.
} 


\section{EMMANOUILIDIS AND KARPETIS Entry Regulation and FDI}

the regulatory Entry barriers could be defined as the difference of the Starting a Business index from the best recorded performance. In other words, for a $i$ country at time $t$, the regulatory barriers to entry could be described by the following equation:

$$
{\text { Entry } \text { Barriers }_{i t}=100-\text { Starting a Business Index }}_{i t}
$$

The examination of the effects of the barriers to entry on FDI inflows is being investigated in the frame of an unbalanced panel consisted of 185 countries. The construction of the employed panel was dependent upon the availability of data associated with the Starting a Business index. Given that the World Bank provides information regarding entry business regulatory climate for 190 countries over the period from 2004 to 2017, the rest variables of our study were set equal to that period. It should be noted, however, that the above-mentioned period is not available across the 190 countries as in 44 of them the data related to the Starting a Business index cover a shorter period of time. Moreover, in 63 countries the last observation, i.e. of the year 2017, is missing due to lack of sufficient information concerning FDI inflows, while five countries out of the total of 190 have been excluded from our sample because of the complete absence of FDI data.

Maps 1 and 2 are the graphical representations of the average values over the sample period of the variables of Entry barriers and FDI inflows, respectively. The color shade of each country corresponds to the magnitude of each index. Thus, the darker shade represents higher values of FDI and barriers to entry. As regards the Entry Barriers, the overall picture that emerges from Map 1 is the existence of excessive business entry regulation in the majority of Latin American, African and South-Eastern Asian countries. This implies that for these specific regions the time, costs and procedures may become burdensome for a new business to start.

Indicative of the high Entry barriers that some countries pose to prospective investors is the example of Venezuela. For this country, the number of days required to start a business was equal to 230 in 2017, while at the same time the cost of creating a new business amounted to $351.6 \%$ of the per capita income. By contrast, the countries of North America, North Asia, Oceania and the majority of European countries offer a much friendlier environment for new entrants. One of the countries with the most favorable entry business environment over the sample period is New Zealand. For this specific country, the number of days for a business to start was just 0.5 , whereas the cost reached $0.3 \%$ of the per capita income in 2017.

Turning to FDI inflows, it is evident from Map 2 that the countries of North America, Eastern and Northern Asia, Oceania, Central Europe as well as Brazil received the highest net 
Map 1. Worldwide Average Entry Barriers, 2004-2017.

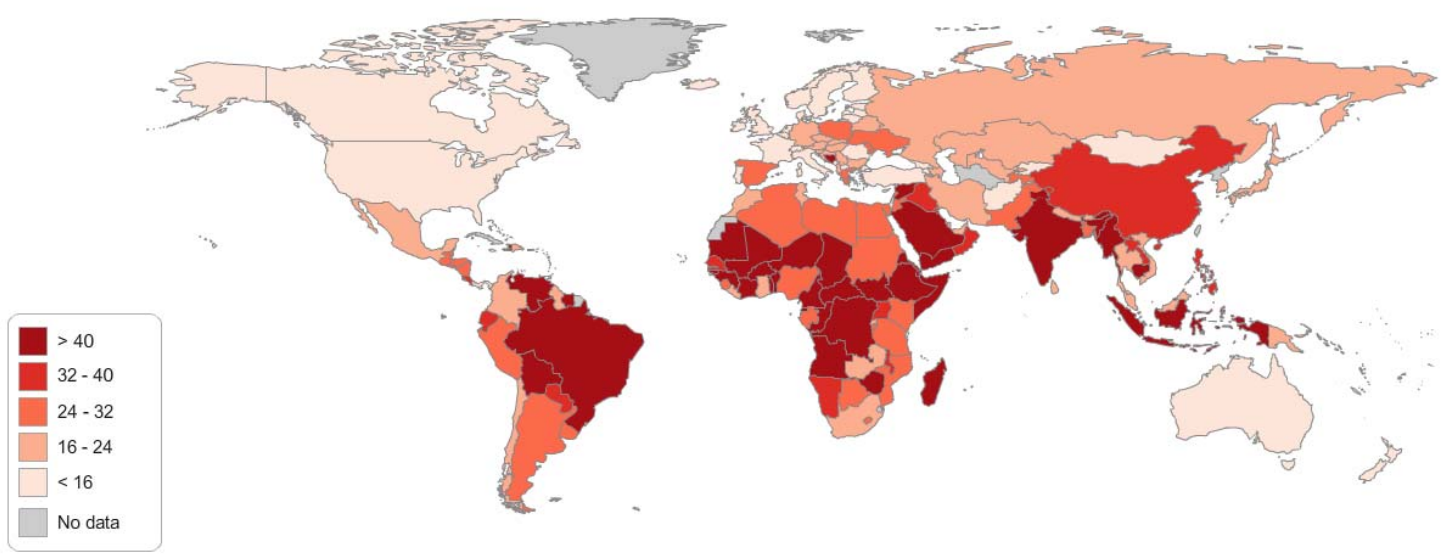

Map 2: Worldwide average FDI inflows (millions current USD), 2004-2017

$>12,000$

9,000 to 12,000

6,000 to 9,000

3,001 to 6,000

$<3,001$

No data
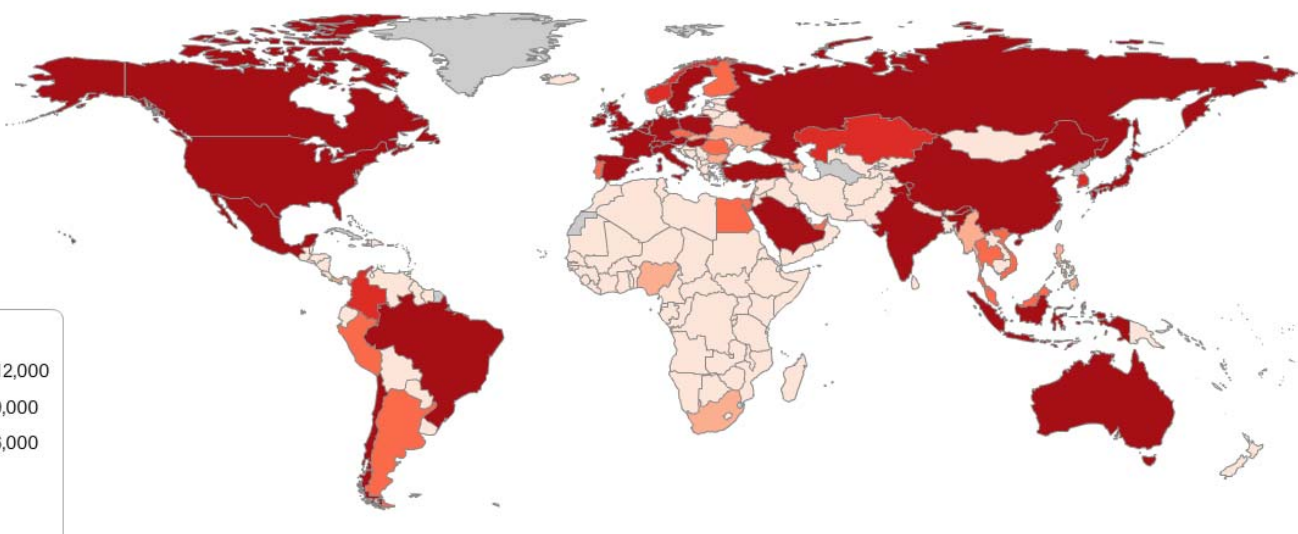

amount of FDI flows in 2017. However, for the rest of Latin America and Europe, and for the majority of African and Middle-East countries, the inflow of foreign capital was at a fairly lower level.

The scatter diagram of the Appendix depicts the linkage between the average values of the natural logarithm of FDI and barriers to entry over the available period of each country. As it was expected, the relationship between the two variables under examination is negative. This implies that countries with a low value of Entry barriers, as defined by equation 1, receive high levels of FDI. However, the determination of significance and magnitude of the impact of entry regulation on FDI inflows requires the execution of a regression analysis. Of course, the estimation of a regression model would be of no importance if no additional factors were 


\section{EMMANOUILIDIS AND KARPETIS Entry Regulation and FDI}

taken into account since entry regulation is not the only factor that could determine the level of FDI. As a result, we also check for additional relevant factors of FDI.

It is a fact that the vast majority of prior empirical literature emphasized the importance of macroeconomic factors in shaping FDI. Among the macroeconomic factors that can influence FDI decisions are GDP growth (\% annual) and inflation (Consumer Price Index, annual change). Although the effects of such variables on FDI can be ambiguous, a higher GDP growth may suggest larger economies of scale (Dhakal et al., 2007) and thus, it can be positively associated with FDI, whereas high rates of inflation in the host nation may imply market instability and, therefore, adverse effects on FDI (Krifa-Schneider and Matei, 2010).

Corporate taxation, which in our case is defined as a percentage of commercial profits, is also another factor that can influence the decisions of foreign investors. However, the impact of corporate taxation on FDI is unclear since it depends on the type of taxation. High tax burdens are associated, in general, with lower profits (Bloningen, 2005; Arbatli, 2011). But issues such as double taxation policy or the imposition of different corporate income and indirect taxation may have individual effects on FDI inflows (Jayasuriya, 2011).

Trade openness, which is defined as the sum of imports and exports as a share of GDP, is a factor that is also taken into account. In general, countries with a higher propensity to trade may be more attractive to foreign investors (Masron and Abdullah, 2010; Economou et al., 2017). Nevertheless, there is also an empirical evidence of insignificant effects on FDI (Walsh and Yu, 2010)

Furthermore, over the last years, several studies dealing with FDI inflows have highlighted the importance of institutional factors in shaping the level of FDI. A common used institutional factor is related to Political Stability and Absence of Violence. According to Asiedu (2006), an unstable political environment can act as a deterrent to FDI inflows.

All data were derived from World Bank's databases. More specifically, the Starting a Business index was obtained from the Doing Business rankings, whereas the variables related to FDI inflows, GDP Growth, Inflation, Total Taxation, and Trade Openness were derived from the World Bank's World Development indicators. Also, the institutional variable of Political Stability and Absence of Violence was obtained from the World Bank's Governance indicators.

After deciding on the appropriate variables that enter the analysis, we proceed with the presentation of the model specification. In particular, the examination of the effects of Entry barriers on FDI is conducted through the estimation of a dynamic panel model the form of which is described by the following equation:

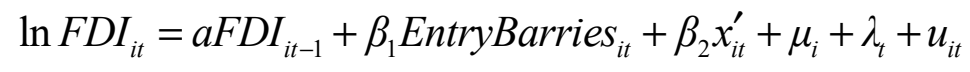


where: $\ln F D I_{i t}$ is the natural logarithm of the net inflow of FDI, EntryBarries ${ }_{i t}$ and $x_{i t}^{\prime}$ represent the barriers to entry and the vector of the rest explanatory variables, respectively, $\mu_{i}$ stands for the unobserved country-specific effects, $\lambda_{t}$ the time period effects and $u_{i t}$ is an error term.

\section{Estimation Strategy}

A significant issue at this point is associated with the estimation of the above-described specification. It is well-known that the standard FE estimator in dynamic panel models produces biased coefficient estimates because of the correlation between the lagged dependent variable and the error term. Several scholars remained in favor of the within estimator as the problem might be insignificant in the special case of long time series since FE estimations become consistent as the time dimension increases (Nickell, 1981).

Provided that the time dimension of our panel contains at best 14 time observations, inconsistency and bias of our dynamic panel model may be better dealt with alternative estimation procedures that can generally improve the efficiency of the estimates. Overall, to alleviate the effects of dynamic panel regression bias either a GMM-type or a bias-corrected fixed-effects estimator can be used. As each one of these estimators has its own advantages and limitations, the estimation of the dynamic specification is based on both types of estimators.

In particular, the bias-corrected fixed-effects estimator used for estimating the dynamic panel model is the one developed by De Vos et al., $(2015)^{3}$. This estimator is an extended version of the bootstrap-based bias-corrected FE estimator proposed by Everaert and Pozzi (2007) in the sense that it accounts for higher-order dynamics and unbalanced panels.

Monte Carlo simulations have shown that the employed estimator compared to estimators with analytical approximation yields similar estimates but better in terms of inference when the time dimension of the panel is relatively small. Also, it is superior to the GMM-type estimators both in terms of estimation and inference in the case of samples with relatively short time and cross-sectional dimension (Everaert \& Pozzi, 2007). Moreover, contrary to other proposed bias-corrected FE estimators (for example Kiviet, 1995; Bun, 2003) this approach does not require an analytical approximation of the bias of the FE estimator as it solves this problem numerically by using an iterative bootstrap algorithm.

Briefly, the bootstrap bias-corrected FE estimator could be described on the basis of the following steps:

\footnotetext{
${ }^{3}$ In relation to the implementation of the bootstrap algorithm, the following assumptions were made: 1) the bootstrap errors used for the calculation of the bootstrap sample were drawn from the normal distribution with country-specific variance in order to take into account potential cross-sectional heteroskedasticity, 2) the initial values for the lags of the dependent variable were specified through an analytical heterogeneous initiation which accounts for cross-country specific means and variance-covariance matrices and 3) the number of bootstrap iterations used for the construction of the corrected FE estimator was set equal to 250 .
} 


\section{EMMANOUILIDIS AND KARPETIS Entry Regulation and FDI}

1) By transforming the original data into deviations from the country specific means, it initially derives the estimated residuals from the following equation:

$$
\hat{\varepsilon}=\tilde{y}-\tilde{W} \delta_{\kappa}^{*}
$$

where: $\tilde{y}$ is the centered dependent variable, $\tilde{W}$ is the $(N T \times k)$ centered matrix containing the regressors and $\delta_{\kappa}^{*}$ is the parameter vector.

2) The estimated residuals $(\hat{\varepsilon})$ are then used to draw $J$ bootstrap errors $\left(\varepsilon^{b}\right)$, which in turn are exploited for the calculation of the bootstrap sample according to the following data generating process:

$$
y^{b}=W^{b} \delta_{\kappa}^{*}+\varepsilon^{b}
$$

with $W^{b}=\left(y_{-1}^{b}, \ldots, y_{-p}^{b}, \tilde{x}\right)$.

3) Next, it applies FE estimation to each one of the $J$ bootstrap samples to obtain a sequence of $J$ biased FE estimators $\left(\hat{\delta}_{1}, \ldots, \hat{\delta}_{j}\right)$

4) The resulted $J$ biased $\mathrm{FE}$ estimates are exploited in the search of the bias-corrected estimator $\left(\hat{\delta}^{b c}\right)$ by calculating an approximation error given as:

$$
\omega_{\kappa}=\hat{\delta}-\frac{1}{J} \sum_{j=1}^{J} \hat{\delta}_{j}^{b}
$$

where $\hat{\delta}$ can be obtained from the original biased fixed-effects estimate.

5) Finally, it updates the parameter vector $\delta_{\kappa}^{*}$ through the following mechanism:

$$
\delta_{\kappa+1}^{*}=\delta_{\kappa}^{*}+\omega_{\kappa}
$$

The search for the bias fixed-effects estimator $\left(\hat{\delta}^{b c}\right)$ is continued until the value of (3d) is close enough to zero or equivalently, the search stops when the value of $\delta^{*}$ satisfies the following condition:

$$
\hat{\delta}=\lim _{J \rightarrow \infty} \frac{1}{J} \sum_{j=1}^{J} \hat{\delta}_{j}
$$

A weakness of the employed estimator, however, is the regressors' exogeneity assumption which can lead to simultaneity bias when some of the regressors are not strictly exogenous. 
As mentioned above, FDI can positively affect economic growth by providing management and marketing skills, technological spillovers, capital flows and foreign exchange. Besides, depending on its type, i.e., market or export-oriented, FDI can have either negative or positive effects on the host nation's balance of trade. For example, market-oriented FDI can be possibly associated with negative effects on the balance of trade as firms of this type tend to export less and import more than the domestic firms (Graham and Krugman, 1989). As a result, given the possibility of reverse causality between FDI and the variables of GDP Growth and Openness to trade, we proceed with the implementation of GMM estimators considering both variables as endogenous.

In sum, the GMM estimator of Arellano \& Bond (1991) involves first-difference transformation to eliminate the individual-effects of each unit that may cause endogeneity due to their correlation with the regressors. By applying first-differences to our dynamic model, equation (2) is transformed as follows:

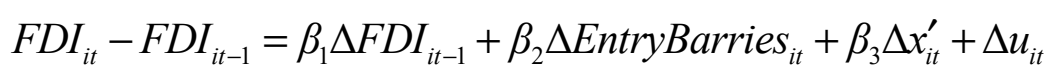

for $i=1, \ldots, N$ and $t=3, \ldots, T$, where the transient errors are serially uncorrelated, $E\left[u_{i t} u_{i s}\right]=0$ for $t \neq s$, and the initial conditions, $F D I_{i 1}$, are predetermined, $E\left[F D I_{i 1} u_{i t}\right]=0$ for $t \geq 2$. Thus, the set of valid instruments consists of the twoperiod or more lagged dependent variable since $F D I_{i t-2}$ is correlated with $\triangle F D I_{i t-1}$ but not with $\Delta u_{i t}$.

The selection of additional instruments from the set of regressors is another crucial issue for applying the GMM estimator. As mentioned above, in the context of the present study GDP Growth and Openness to Trade are considered as endogenous variables. Thus, the moment conditions exploited by the first-difference GMM estimator are:

$$
E\left[\Delta u_{i t} y_{i t-s}\right]=0 \quad(5 \mathrm{a}), \quad E\left[\Delta u_{i t} z_{i t-s}\right]=0
$$

where $s \geq 2$ and $t=3, \ldots, T$ and $z_{i t}$ the vector of endogenous regressors.

As a result, the two-period lagged GDP Growth and Openness to Trade can be also used as valid instruments. This procedure leads to a consistent estimator of the coefficient values as $N \rightarrow \infty$ and $T$ is fixed.

However, an issue that should be taken into consideration is that the difference transformation exploited by the difference GMM estimator omits valuable information by reducing the time dimension of the sample, especially when there are several missing values as in our case. Additionally, the use of lagged explanatory variables as instruments may work poorly in some cases. According to Arellano \& Bover (1995) and Blundell \& Bond (1998) lagged explanatory variables can be regarded as weak instruments when the series of these 


\section{EMMANOUILIDIS AND KARPETIS Entry Regulation and FDI}

variables are persistent, a fact that can result to bias and low precision of the first-difference GMM estimator.

For that reason, we also provide evidence from the proposed by Blundell and Bond (1998) system GMM estimator that combines equations in first-differences with equations in levels. This method produces more efficient and consistent estimates and reduces the finite-sample bias of the difference GMM by adding a stationarity restriction on the following additional assumption:

$$
E\left[\mu_{i} \Delta y_{i 2}\right]=0 \quad(6 a), \quad E\left[\mu_{i} \Delta z_{i t}\right]=0
$$

This additional restriction allows the use of lagged variables in differences as instruments in level equation in conjunction with lagged instruments of first differenced equation.

It should be also noted that our GMM results are based on second-step estimates. In such case, standard errors although robust to any pattern of autocorrelation and heteroskedasticity can be severely downward biased (Blundell and Bond, 1998). For that reason, we exploit the Windmeijer's (2005) finite sample correction to gain more efficient robust estimations.

\section{Empirical Results}

The results of the various dynamic estimators are summarized in Table 1. In general, our findings support partially the hypothesized negative association between entry regulation and inward FDI. On the one hand, the derived estimates from the FE-type and system GMM suggest a statistically significant, at least at a $10 \%$ level of significance, impact of Entry barriers on the inflow of FDI. This implies that improvements in the entry regulatory environment are capable of affecting the level of foreign capital entering a specific economy. Such a conclusion is consistent with Olival (2012), Shahadan et al. (2014) and Bayraktar (2015) but contradicts a large body of the relative literature, which argues that the entry regulatory environment does not play an active role in shaping the level of FDI (Corcoran and Gillandres, 2015; Jayasuriya, 2011; Jovanovic and Jovanovic, 2015; Hossain et al., 2018; Morris and Azis, 2011). On the other hand, the results from the difference GMM indicate insignificant effects of the regulation to entry on the natural logarithm of FDI, implying that the procedures, costs and days required starting a business are not an obstacle for foreign investors.

Also, the magnitude of the effect of the index as reflected by its estimated coefficient values ranges from -0.0049 to -0.0064 . Based on these results, we conclude that an increase in Entry barriers, as defined by equation (1), by one unit is capable of reducing FDI from 0.49 $\%$ to $0.64 \%$. At the same time, the average percentage change in FDI because of a unit change in barriers to entry is equal to $0.56 \%$. 
Review of Economic Analysis 11 (2019) 175-202

Table 1. Dynamic panel estimates

\begin{tabular}{|c|c|c|c|c|}
\hline Variables & Fixed Effects & $\begin{array}{c}\text { Bootstrap } \\
\text { Fixed Effects }\end{array}$ & $\begin{array}{l}\text { Difference } \\
\text { GMM }\end{array}$ & System GMM \\
\hline Lagged FDI & $\begin{array}{l}0.2869 * * * \\
(0.0355)\end{array}$ & $\begin{array}{l}0.4611 * * * \\
(0.0415)\end{array}$ & $\begin{array}{l}0.2547 * * * \\
(0.0694)\end{array}$ & $\begin{array}{l}0.8718 * * * \\
(0.0510)\end{array}$ \\
\hline Entry barriers & $-0.0055^{*}$ & $-0.0064 * * *$ & -0.0034 & $-0.0049 *$ \\
\hline & $\begin{array}{l}(0.0032) \\
-0.0006\end{array}$ & $\begin{array}{l}(0.0023) \\
-0.0002\end{array}$ & $\begin{array}{l}(0.0063) \\
0.0068 * *\end{array}$ & $\begin{array}{l}(0.0026) \\
0.0038\end{array}$ \\
\hline Inflation & $(0.0027)$ & $(0.0023)$ & $(0.0028)$ & $(0.0030)$ \\
\hline GDP growth & $\begin{array}{l}0.0332 * * * \\
(0.0072)\end{array}$ & $\begin{array}{l}0.0369 * * * \\
(0.0053)\end{array}$ & $\begin{array}{l}0.0215 \\
(0.0157)\end{array}$ & $\begin{array}{l}0.0442 * * * \\
(0.0133)\end{array}$ \\
\hline Openness to trade & $\begin{array}{l}0.0018 \\
(0.0021)\end{array}$ & $\begin{array}{l}0.0029 \\
(0.0017)\end{array}$ & $\begin{array}{l}-0.0013 \\
(0.0058)\end{array}$ & $\begin{array}{l}-0.0001 \\
(0.0011)\end{array}$ \\
\hline Political stability \& & 0.0003 & 0.0007 & -0.0022 & 0.0013 \\
\hline Absence of violence & $(0.0019)$ & $(0.0014)$ & $(0.0025)$ & $(0.0013)$ \\
\hline Total taxation & $\begin{array}{l}-0.0013 \\
(0.0017)\end{array}$ & $\begin{array}{l}-0.0011 \\
(0.0023)\end{array}$ & $\begin{array}{l}-0.0006 \\
(0.0025)\end{array}$ & $\begin{array}{l}-0.0002 \\
(0.0008)\end{array}$ \\
\hline Constant & $\begin{array}{l}14.3946^{* * *} \\
(0.8513)\end{array}$ & - & - & $\begin{array}{l}2.4587 * * \\
(1.1138)\end{array}$ \\
\hline Year 2004 & - & - & - & \\
\hline Year 2005 & - & - & $\begin{array}{l}-0.1548 \\
(0.2300)\end{array}$ & $\begin{array}{l}0.4058 * * * \\
(0.1509)\end{array}$ \\
\hline Year 2006 & $\begin{array}{l}0.1464 \\
(0.1017)\end{array}$ & - & $\begin{array}{l}0.0780 \\
(0.1934)\end{array}$ & $\begin{array}{l}0.3474 * * \\
(0.1441)\end{array}$ \\
\hline Year 2007 & $\begin{array}{l}0.5353 * * * \\
(0.0795)\end{array}$ & - & $\begin{array}{l}0.4259^{* *} \\
(0.1861)\end{array}$ & $\begin{array}{l}0.4982 * * * \\
(0.1323)\end{array}$ \\
\hline Year 2008 & $\begin{array}{l}0.3455^{* * * *} \\
(0.0946)\end{array}$ & - & $\begin{array}{l}0.2615 \\
(0.1877)\end{array}$ & $\begin{array}{l}0.0586 \\
(0.1328)\end{array}$ \\
\hline Year 2009 & $\begin{array}{l}0.1635 \\
(0.1108)\end{array}$ & - & $\begin{array}{l}0.0130 \\
(0.2157)\end{array}$ & \\
\hline Year 2010 & $\begin{array}{l}0.3419 * * * \\
(0.1036)\end{array}$ & - & $\begin{array}{l}0.2150 \\
(0.1719)\end{array}$ & $\begin{array}{l}0.2462 * \\
(0.1383)\end{array}$ \\
\hline Year 2011 & $\begin{array}{l}0.5012 * * * \\
(0.1035)\end{array}$ & - & $\begin{array}{l}0.4043 * * \\
(0.1744)\end{array}$ & $\begin{array}{l}0.3582 * * * \\
(0.1268)\end{array}$ \\
\hline Year 2012 & $\begin{array}{l}0.3495 * * * \\
(0.1230)\end{array}$ & - & $\begin{array}{l}0.2941^{*} \\
(0.1563)\end{array}$ & $\begin{array}{l}0.0674 \\
(0.1203)\end{array}$ \\
\hline Year 2013 & $\begin{array}{l}0.3105^{* * * *} \\
(0.1130)\end{array}$ & - & $\begin{array}{l}0.2126 \\
(0.1628)\end{array}$ & $\begin{array}{l}0.0847 \\
(0.1221)\end{array}$ \\
\hline Year 2014 & $\begin{array}{l}0.3269 * * * \\
(0.1106)\end{array}$ & - & $\begin{array}{l}0.1864 \\
(0.1548)\end{array}$ & $\begin{array}{l}0.0894 \\
(0.1245)\end{array}$ \\
\hline Year 2015 & $\begin{array}{l}0.2708^{* *} \\
(0.1138)\end{array}$ & - & $\begin{array}{l}0.0867 \\
(0.1521)\end{array}$ & $\begin{array}{l}0.0289 \\
(0.1165)\end{array}$ \\
\hline
\end{tabular}


EMMANOUILIDIS AND KARPETIS Entry Regulation and FDI

Table 1 continued

\begin{tabular}{|l|l|l|l|l|}
\hline Variables & $\begin{array}{l}\text { Fixed } \\
\text { Effects }\end{array}$ & $\begin{array}{l}\text { Bootstrap } \\
\text { Fixed Effects }\end{array}$ & $\begin{array}{l}\text { Difference } \\
\text { GMM }\end{array}$ & $\begin{array}{l}\text { System } \\
\text { GMM }\end{array}$ \\
\hline \hline Year 2016 & 0.2089 & - & 0.0164 & 0.0425 \\
& $(0.1267)$ & - & $(0.1307)$ & $(0.1177)$ \\
Year 2017 & $0.3304^{* *}$ & - & - & $0.2985^{* *}$ \\
& $(0.1531)$ & - & $16.1277)$ \\
Number of obs. & 1836 & 1751 & - & 1836 \\
$\mathrm{R}^{2}$ within & 0.1792 & - & 142 & - \\
Instruments & - & - & 0.000 & 140 \\
AR(1) & - & - & 0.086 & 0.002 \\
AR(2) & - & - & 0.104 & 0.280 \\
Overidentification & - & - & 0.326 \\
Test & & & & \\
\hline
\end{tabular}

Note: $*, * *, * * *$ denote significance at 10,5 and $1 \%$ levels of significance, respectively. Standard errors, which are presented in parentheses, are robust in the presence of any pattern of autocorrelation and heteroskedasticity.

Turning to the lagged dependent variable, it is evident that the Lagged FDI is a positive and statistically significant determinant in all cases supporting thus the need of investigating the issue into a dynamic framework. Moreover, the autoregressive estimated coefficient values give rise to another interesting conclusion. According to Bond et al. (2001) a first-difference GMM estimate of the autoregressive coefficient, $a$, which lies close to or below the FE estimator could be regarded as a signal of bias, possibly due to weak instruments. Although this practical rule was originally proposed for growth models, it has been extended to models with other regressors under the assumption of regressors' exogeneity with respect to $u_{i t}$ and uncorrelatedness with $\mu_{i}$. Nevertheless, Bond et al. (2001) asserted that it is still useful to compare results derived from first-difference GMM with those of within estimation. In this context, therefore, and given that the estimated lagged value of the first-difference GMM lies fairly below the FE estimator, we conclude that the first-difference GMM can be also downward biased. Relying on these results, the Bootstrap FE and system GMM are considered as our preferred estimators.

As for the rest explanatory variables, GDP growth exerts a positive and statistically significant impact on FDI in all employed estimators with the exception of difference GMM. Of course, a positive effect of GDP growth on FDI is not surprising as countries with higher growth rates may attract more FDI due to the realization of economies of scale, which can lead to lower costs of production (Walsh and $\mathrm{Yu}, 2010$ ). Moreover, higher growth prospects can be a signal for a higher level of aggregate demand which can lead in turn to greater incentives to invest (Zhang, 2001). 
Another variable from the set of regressors that seems to affect the level of FDI is the Inflation rate. More specifically, the results reveal a statistically significant impact of Inflation on the inflow of FDI in the context of the difference GMM. Of course, the positive effect of inflation does not fulfill the expectation of a negative association between Inflation and FDI which has been highlighted in prior literature (Krifa-Schneider and Matei, 2010; Khan and Mitra, 2014; Sayek, 2009). High rates of Inflation in the host nation can be regarded as a signal of economic uncertainty and market instability which could discourage prospective investors. In addition, an increased Inflation can be associated with a fast erosion of the profits made by the foreign investors or with high nominal interest rates that translate into high cost of capital. Apart from being a source of uncertainty, however, Inflation can act as a lubricant in the economy, known as grease hypothesis, by reducing the rigidity of nominal prices and wages. Thus, inflation at a moderate level could improve labor market efficiency in reducing real wages when nominal wages are downward rigid (Card and Hyslop, 1997).

Furthermore, the impact of Total taxation, as one might expect, appears to be negative across the various estimators but in none of the cases, it is a statistically significant determinant of FDI. Indeed, the inflow of FDI can be insensitive to the host countries' corporate taxation. As firms can place their profits in countries with low tax burdens by applying intra-firm contracting and transfer pricing, they are able to discriminate their profits from the location of production (Bénassy-Quére et al., 2005).

Also, when high tax burden is matched with other factors such as developed infrastructure and provision of public goods, it may not be a detrimental factor for the choice of FDI location. Evidence from OECD countries suggests that countries with relatively high effective tax rates are successful in FDI attraction. For example, countries with large domestic markets and high FDI inflows such as Canada, United States, Germany and Japan are among countries with the highest corporate taxation (OECD, 2008).

As regards the impact of the Openness to trade, empirical evidence suggests a negative one in the case of the GMM-type estimators and positive in the case of the FE-type estimators. Nevertheless, its relationship with the dependent variable seems to be insignificant. This implies that Openness to trade may not really matter for FDI attractiveness. The absence of any significant association between Openness to trade and FDI could be possibly attributed to the heterogeneity of FDI inflows. A sectoral analysis of Walsh and $\mathrm{Wu}$ (2010) indicated that trade openness matters for FDI only in the case of the tertiary sector while for rest two sectors and the aggregate FDI inflows no significant effects were found.

Moreover, the estimated coefficients of the variable of Political stability and Absence of violence suggest a positive affection of FDI across the estimators with the exception of difference GMM. A positive sign implies that countries with high (low) degree of Political stability and Absence of violence can be more (less) attractive to foreign investors. This is 


\section{EMMANOUILIDIS AND KARPETIS Entry Regulation and FDI}

because a highly unstable political environment can be associated with great volatility to exchange rates and growing inflation. In addition, governments of those countries may be unable to collect or raise taxes, which in turn may lead to less investment in infrastructure. As in the case of Openness to trade, however, the results related to Political stability and Absence of violence show no connection with FDI since all the estimated coefficients are statistically insignificant. A statistically insignificant relationship between Political stability and Absence of violence and FDI could be the result of heterogeneity within the sample. Empirical evidence from Kurecic and Kokotovic (2017) for instance, suggested that political stability is relevant in determining the level of FDI only in small economies whereas for a group of developed and large emerging economies an unstable political environment is not crucial for the decisions of foreign investors.

Another interesting conclusion resulting from the findings of Table 1 is related to the timeperiod effects that are described in the frame of the coefficient values of the time dummies. The results generally reveal a positive linkage between the dependent variable and the timeperiod effects. However, this relationship appears to be statistically significant mainly in the case of the FE estimator since for the difference GMM and system GMM estimators, significance arises only in a few years. Of course, various reasons could lie behind the positive signs of the time-period effects. It is a fact that many countries made strenuous efforts to improve their business climate over the last decade. More specifically, the average percentage decrease in barriers to entry reached $5.52 \%$ during the sample period. Moreover, $64.7 \%$ of the recorded countries in the Doing Business rankings implemented at least one regulatory reform for the last three consecutive years (World Bank, Doing Business report, 2018). Another reason could be associated with the economic rise of several countries also known as emerging economies. The implementation of economic reforms over the last decades combined with the competitive advantages they offer has resulted not only in their rapid economic growth but has also transformed them among the greatest recipients of FDI. Countries like China and India have undergone remarkable increases in the inflows of foreign capital. In terms of deflated FDI, the annual average percentage increase over the sample period reached $6.5 \%$ and $18.1 \%$ in the former and the latter, respectively.

Finally, as an empirical related issue to the GMM estimators, we applied two specification tests. The first is a test for over-identifying restrictions which examines whether the employed instruments are in fact exogenous and the second is an autocorrelation test that investigates the presence of a second-order serial correlation in the disturbances of the first-differenced equations. The reported values of Hansen's statistic for over-identifying restrictions imply that the instruments are not correlated with the errors in both GMM estimations. Also, the values of Arellano-Bond's test for serial correlation suggest the absence of a second-order correlation in the first-differenced residuals implying the consistency of the GMM estimators. 


\section{Income Heterogeneity}

The above-presented GMM-type and FE estimates rely on the assumption of homogeneity of the slope parameters which implies that different countries are treated as a united entity. One way to circumvent that issue is to separate the sample into different data stratifications based on countries' level of income. In order to carry out estimations with a sufficient number of observations, we separate the sample into Low \& Lower-middle, Upper-middle and High income countries following World Bank's income categorizations.

The number of countries included in each income group is 80, 51 and 54 for the Low \& Lower-middle, Upper-middle and High-income countries, respectively. Regarding the geographical distribution of the countries in the three income groups, it is worth mentioning that the countries comprise the Low \& Lower-middle income group are mainly from Latin America, Sub-Saharan Africa, Middle East, Central and Southern Asia, and Eastern Europe whereas a similar geographical distribution is being observed for the Upper-middle income group as well. On the other hand, the countries that constitute the group of High-income countries are mainly located in Europe, East Asia, Oceania and North America.

As expected, there are significant differences among the three sub-samples with respect to the entry business climate. As clearly illustrated in Map 1, the majority of countries belonging to the Low \& Lower-middle income group pose significant entry barriers to prospective investors. In this specific group, only the $13.75 \%$ is represented in the top 50 ranking of the most favorable entry regulatory environments for 2017, with the corresponding percentage for the Upper-middle and High-income groups being equal to $25.5 \%$ and $48.1 \%$, respectively. In addition, the data of Table 3 of the Appendix, which illustrates the average value of Entry Barriers over the sample period based on income classification, reveal that the Low \& Lowermiddle income countries pose on average 1.46 and 2.2 times higher entry barriers for the new entrants compared to the Upper-middle and High-income groups, respectively. It should be noted, however, that there is a trend towards improving the investment climate in areas with heavy business regulation. The reduction of Entry Barriers in the first income group is particularly evident in Diagram 2 of the Appendix, which illustrates, among others, the evolution of the average value of the index for each income group.

With respect to the inflow of FDI, the value of investments received by High-income countries is considerably higher than that of the other two income groups. This becomes apparent from the data of Table 3, which also demonstrates the average value of FDI over the sample period according to income classification. Specifically, the average FDI inflows received by High-income countries amounts to 28,184 (billion USD), while the corresponding value of foreign investments for the Low and Lower-middle, and Upper-middle income groups amounts only to 1.248 and 9.044 (billion USD), respectively. With regard to the diachronic evolution of the dependent variable as shown in Diagram 2 of the Appendix, the 
EMMANOUILIDIS AND KARPETIS Entry Regulation and FDI

Table 2. Dynamic Panel Eestimates

\begin{tabular}{|c|c|c|c|c|c|c|c|c|}
\hline Variables & \multicolumn{4}{|c|}{ Low and Lower-Middle income } & \multicolumn{4}{|c|}{ Upper-Middle income } \\
\hline & $\begin{array}{l}\text { Fixed } \\
\text { Effects }\end{array}$ & $\begin{array}{l}\text { Bootstrap } \\
\text { Fixed } \\
\text { Effects }\end{array}$ & $\begin{array}{c}\text { Difference } \\
\text { GMM }\end{array}$ & $\begin{array}{l}\text { System } \\
\text { GMM }\end{array}$ & $\begin{array}{l}\text { Fixed } \\
\text { Effects }\end{array}$ & $\begin{array}{l}\text { Bootstrap } \\
\text { Fixed } \\
\text { Effects }\end{array}$ & $\begin{array}{l}\text { Differenc } \\
\text { e GMM }\end{array}$ & $\begin{array}{l}\text { System } \\
\text { GMM }\end{array}$ \\
\hline Lagged FDI & $\begin{array}{l}0.3269 * * * \\
(0.0480)\end{array}$ & $\begin{array}{l}0.5792 * * * \\
(0.0651)\end{array}$ & $\begin{array}{l}0.1988^{* *} \\
(0.0963)\end{array}$ & $\begin{array}{l}0.3476^{* *} \\
(0.1706)\end{array}$ & $\begin{array}{l}0.2623 * * * \\
(0.0754)\end{array}$ & $\begin{array}{l}0.4361 * * * \\
(0.0678)\end{array}$ & $\begin{array}{l}0.1493 \\
(0.1464)\end{array}$ & $\begin{array}{l}0.5934 * * * \\
(0.1865)\end{array}$ \\
\hline Entry barriers & $\begin{array}{l}-0.0033 \\
(0.0043)\end{array}$ & $\begin{array}{l}-0.0068^{* *} \\
(0.0033)\end{array}$ & $\begin{array}{l}-0.0079 \\
(0.0105)\end{array}$ & $\begin{array}{l}-0.0097^{*} \\
(0.0056)\end{array}$ & $\begin{array}{l}-0.0058 \\
(0.0070)\end{array}$ & $\begin{array}{l}-0.0098 * * \\
(0.0048)\end{array}$ & $\begin{array}{l}-0.0015 \\
(0.0132)\end{array}$ & $\begin{array}{l}-0.0079 \\
(0.0080)\end{array}$ \\
\hline Inflation & $\begin{array}{l}0.0106^{* * *} \\
(0.0040)\end{array}$ & $\begin{array}{l}0.0114 \\
(0.0070)\end{array}$ & $\begin{array}{l}0.0091^{*} \\
(0.0052)\end{array}$ & $\begin{array}{l}0.0170 * * * \\
(0.0063)\end{array}$ & $\begin{array}{l}0.0079 * * \\
(0.0038)\end{array}$ & $\begin{array}{l}0.0084 * * \\
(0.0041)\end{array}$ & $\begin{array}{l}0.0024 \\
(0.0056)\end{array}$ & $\begin{array}{l}0.0091 \\
(0.0106)\end{array}$ \\
\hline GDP growth & $\begin{array}{l}0.0237^{* *} \\
(0.0092)\end{array}$ & $\begin{array}{l}0.0281 * * * \\
(0.0069)\end{array}$ & $\begin{array}{l}-0.0540^{* *} \\
(0.0211)\end{array}$ & $\begin{array}{l}0.0465 \\
(0.0320)\end{array}$ & $\begin{array}{l}0.0327 * * * \\
(0.0115)\end{array}$ & $\begin{array}{l}0.0337 * * * \\
(0.0085)\end{array}$ & $\begin{array}{l}0.0034 \\
(0.0524)\end{array}$ & $\begin{array}{l}-0.0305 \\
(0.0350)\end{array}$ \\
\hline Openness to trade & $\begin{array}{l}0.0065^{* *} \\
(0.0032)\end{array}$ & $\begin{array}{l}0.0050^{*} \\
(0.0027)\end{array}$ & $\begin{array}{l}0.0039 \\
(0.0139)\end{array}$ & $\begin{array}{l}0.0114 \\
(0.0148)\end{array}$ & $\begin{array}{l}-0.0002 \\
(0.0033)\end{array}$ & $\begin{array}{l}0.0020 \\
(0.0031)\end{array}$ & $\begin{array}{l}0.0074 \\
(0.0070)\end{array}$ & $\begin{array}{l}0.0004 \\
(0.0071)\end{array}$ \\
\hline $\begin{array}{l}\text { Political stability \& } \\
\text { Absence of } \\
\text { violence }\end{array}$ & $\begin{array}{l}0.0016 \\
(0.0036)\end{array}$ & $\begin{array}{l}0.0012 \\
(0.0024)\end{array}$ & $\begin{array}{l}0.0005 \\
(0.0055)\end{array}$ & $\begin{array}{l}-0.019 * * \\
(0.0094)\end{array}$ & $\begin{array}{l}0.0047 \\
(0.0042)\end{array}$ & $\begin{array}{l}0.0020 \\
(0.0024)\end{array}$ & $\begin{array}{l}-0.0041 \\
(0.0056)\end{array}$ & $\begin{array}{l}-0.0182^{*} \\
(0.0098)\end{array}$ \\
\hline Total taxation & $\begin{array}{l}-0.0004 \\
(0.0017)\end{array}$ & $\begin{array}{l}-0.0001 \\
(0.0026)\end{array}$ & $\begin{array}{l}0.0012 \\
(0.0022)\end{array}$ & $\begin{array}{l}-0.0043 \\
(0.0029)\end{array}$ & $\begin{array}{l}-0.00035 \\
(0.0050)\end{array}$ & $\begin{array}{l}-0.0012 \\
(0.0041)\end{array}$ & $\begin{array}{l}-0.0100 \\
(0.0085)\end{array}$ & $\begin{array}{l}0.0094 \\
(0.0086)\end{array}$ \\
\hline Constant & $\begin{array}{l}12.0273 \\
(1.1057)\end{array}$ & - & - & $\begin{array}{l}12.5115^{* * *} \\
(3.2809)\end{array}$ & $\begin{array}{l}14.8089 * * \\
* \\
(1.7543)\end{array}$ & - & - & $\begin{array}{l}8.4500^{*} \\
(4.5084)\end{array}$ \\
\hline Year 2005 & & - & $\begin{array}{l}-0.1550 \\
(0.1741)\end{array}$ & $\begin{array}{l}-0.0777 \\
(0.3789)\end{array}$ & & - & $\begin{array}{l}-0.1740 \\
(0.4986)\end{array}$ & $\begin{array}{l}0.6052 * \\
(0.3062)\end{array}$ \\
\hline Year 2006 & $\begin{array}{l}0.0683 \\
(0.1551)\end{array}$ & - & - & $\begin{array}{l}-0.0384 \\
(0.3965)\end{array}$ & $\begin{array}{l}0.1914 \\
(0.2025)\end{array}$ & - & $\begin{array}{l}0.0897 \\
(0.5389)\end{array}$ & $\begin{array}{l}0.8207 * * \\
(0.3824)\end{array}$ \\
\hline Year 2007 & $\begin{array}{l}0.6314 * * * \\
(0.1431)\end{array}$ & - & $\begin{array}{l}0.4846^{* * *} \\
(0.1690)\end{array}$ & $\begin{array}{l}0.3475 \\
(0.3127)\end{array}$ & $\begin{array}{l}0.5059 * * * \\
(0.1182)\end{array}$ & - & $\begin{array}{l}0.3314 \\
(0.4375)\end{array}$ & $\begin{array}{l}0.8667 * * \\
(0.3340)\end{array}$ \\
\hline Year 2008 & $\begin{array}{l}0.2903^{*} \\
(0.1478)\end{array}$ & - & $\begin{array}{l}0.1943 \\
(0.1757)\end{array}$ & $\begin{array}{l}0.0064 \\
(0.3129)\end{array}$ & $\begin{array}{l}0.6076^{* * * *} \\
(0.1387)\end{array}$ & - & $\begin{array}{l}0.3876 \\
(0.3187)\end{array}$ & $\begin{array}{l}0.7139 * * \\
(0.2973)\end{array}$ \\
\hline Year 2009 & $\begin{array}{l}0.4135^{* *} \\
(0.1636)\end{array}$ & - & $\begin{array}{l}-0.0031 \\
(0.2214)\end{array}$ & $\begin{array}{l}0.2760 \\
(0.2896)\end{array}$ & $\begin{array}{l}0.2469 \\
(0.1503)\end{array}$ & - & & - \\
\hline Year 2010 & $\begin{array}{l}0.5751 * * * \\
(0.1429)\end{array}$ & - & $\begin{array}{l}0.4080^{* *} \\
(0.2029)\end{array}$ & $\begin{array}{l}0.2378 \\
(0.2891)\end{array}$ & $\begin{array}{l}0.3088^{*} \\
(0.1701)\end{array}$ & - & $\begin{array}{l}0.0134 \\
(0.3352)\end{array}$ & $\begin{array}{l}0.4983 * \\
(0.2922)\end{array}$ \\
\hline Year 2011 & $\begin{array}{l}0.7572 * * * \\
(0.1623)\end{array}$ & - & $\begin{array}{l}0.6383 * * \\
(0.2575)\end{array}$ & $\begin{array}{l}0.4445^{*} \\
(0.2564)\end{array}$ & $\begin{array}{l}0.5121 * * * \\
(0.1682)\end{array}$ & - & $\begin{array}{l}0.2169 \\
(0.3344)\end{array}$ & $\begin{array}{l}0.6368 * * \\
(0.2615)\end{array}$ \\
\hline Year 2012 & $\begin{array}{l}0.5685^{* * *} \\
(0.1569)\end{array}$ & - & $\begin{array}{l}0.4724^{*} \\
(0.2582)\end{array}$ & $\begin{array}{l}0.2127 \\
(0.2921)\end{array}$ & $\begin{array}{l}0.5167 * * * \\
(0.1697)\end{array}$ & - & $\begin{array}{l}0.1474 \\
(0.2619)\end{array}$ & $\begin{array}{l}0.5250 * * \\
(0.2375)\end{array}$ \\
\hline Year 2013 & $\begin{array}{l}0.5913 * * * \\
(0.1639)\end{array}$ & - & $\begin{array}{l}0.3572 \\
(0.3249)\end{array}$ & $\begin{array}{l}0.3147 \\
(0.2765)\end{array}$ & $\begin{array}{l}0.4762 * * * \\
(0.1577)\end{array}$ & - & $\begin{array}{l}0.1370 \\
(0.2579)\end{array}$ & $\begin{array}{l}0.6913 * * \\
(0.2632)\end{array}$ \\
\hline Year 2014 & $\begin{array}{l}0.6110 * * * \\
(0.1671)\end{array}$ & - & $\begin{array}{l}0.2627 \\
(0.3177)\end{array}$ & $\begin{array}{l}0.2747 \\
(0.3078)\end{array}$ & $\begin{array}{l}0.3461 * * \\
(0.1661)\end{array}$ & - & $\begin{array}{l}0.0014 \\
(0.2605)\end{array}$ & $\begin{array}{l}0.5474^{*} \\
(0.3058)\end{array}$ \\
\hline Year 2015 & $\begin{array}{l}0.5910 * * * \\
(0.1727)\end{array}$ & - & $\begin{array}{l}0.2402 \\
(0.2937)\end{array}$ & $\begin{array}{l}0.1935 \\
(0.3074)\end{array}$ & $\begin{array}{l}0.4580 * * \\
(0.1801)\end{array}$ & - & $\begin{array}{l}0.0592 \\
(0.2381)\end{array}$ & $\begin{array}{l}0.6933 * * * \\
(0.2513)\end{array}$ \\
\hline Year 2016 & $\begin{array}{l}0.4201 * * \\
(0.1992)\end{array}$ & - & $\begin{array}{l}-0.0293 \\
(0.3199)\end{array}$ & $\begin{array}{l}0.1488 \\
(0.2938)\end{array}$ & $\begin{array}{l}0.2418 \\
(0.2022)\end{array}$ & - & $\begin{array}{l}0.0095 \\
(0.2571)\end{array}$ & $\begin{array}{l}0.6903 * * \\
(0.3088)\end{array}$ \\
\hline
\end{tabular}


Review of Economic Analysis 11 (2019) 175-202

Table 2 continued

\begin{tabular}{|c|c|c|c|c|c|c|c|c|}
\hline Variables & \multicolumn{4}{|c|}{ Low and Lower-Middle income } & \multicolumn{4}{|c|}{ Upper-Middle income } \\
\hline & $\begin{array}{l}\text { Fixed } \\
\text { Effects }\end{array}$ & $\begin{array}{l}\text { Bootstrap } \\
\text { Fixed } \\
\text { Effects }\end{array}$ & $\begin{array}{c}\text { Difference } \\
\text { GMM }\end{array}$ & $\begin{array}{l}\text { System } \\
\text { GMM }\end{array}$ & $\begin{array}{l}\text { Fixed } \\
\text { Effects }\end{array}$ & $\begin{array}{l}\text { Bootstrap } \\
\text { Fixed } \\
\text { Effects }\end{array}$ & $\begin{array}{l}\text { Differenc } \\
\text { e GMM }\end{array}$ & $\begin{array}{l}\text { System } \\
\text { GMM }\end{array}$ \\
\hline Year 2017 & $\begin{array}{l}0.6328 * * * \\
(0.1941)\end{array}$ & - & $\begin{array}{l}0.0825 \\
(0.3935)\end{array}$ & - & $\begin{array}{l}0.5116^{* *} \\
(0.2363)\end{array}$ & - & $\begin{array}{l}-0.2004 \\
(0.3524)\end{array}$ & $\begin{array}{l}0.0787 \\
(0.2615)\end{array}$ \\
\hline Number of obs. & 794 & 757 & 705 & 794 & 536 & 526 & 481 & 536 \\
\hline $\mathrm{R}^{2}$ within & 0.2729 & - & - & - & 0.2130 & - & - & \\
\hline Instruments & - & - & 28 & 86 & - & - & 37 & 44 \\
\hline $\mathrm{AR}(1)$ & - & - & 0.000 & 0.015 & - & - & 0.015 & 0.003 \\
\hline $\mathrm{AR}(2)$ & - & - & 0.586 & 0.840 & - & - & 0.382 & 0.132 \\
\hline $\begin{array}{l}\text { Overidentification } \\
\text { Test }\end{array}$ & - & - & 0.447 & 0.637 & - & - & 0.104 & 0.079 \\
\hline
\end{tabular}

\begin{tabular}{|c|c|c|c|c|}
\hline \multirow[t]{2}{*}{ Variables } & \multicolumn{4}{|c|}{ High income } \\
\hline & $\begin{array}{l}\text { Fixed } \\
\text { Effects }\end{array}$ & $\begin{array}{l}\text { Bootstrap } \\
\text { Fixed } \\
\text { Effects }\end{array}$ & $\begin{array}{c}\text { Difference } \\
\text { GMM }\end{array}$ & $\begin{array}{l}\text { System } \\
\text { GMM }\end{array}$ \\
\hline Lagged FDI & $\begin{array}{l}-0.2203^{* *} \\
(0.0836)\end{array}$ & $\begin{array}{l}-0.1819 \\
(0.2079)\end{array}$ & $\begin{array}{l}-0.5364 * * * \\
(0.0839)\end{array}$ & $\begin{array}{l}-0.4220^{* *} \\
(0.1613)\end{array}$ \\
\hline Entry barriers & $\begin{array}{l}-0.0137 \\
(0.0114)\end{array}$ & $\begin{array}{l}-0.0026 \\
(0.0062)\end{array}$ & $\begin{array}{l}-0.0147 \\
(0.0142)\end{array}$ & $\begin{array}{l}-0.0609 * \\
(0.0327)\end{array}$ \\
\hline Inflation & 0.0001 & 0.01345 & 0.0019 & -0.0249 \\
\hline & $\begin{array}{l}(0.0099) \\
0.0891 * * *\end{array}$ & $\begin{array}{l}(0.0084) \\
0.1035^{* * *}\end{array}$ & $\begin{array}{l}(0.0085) \\
0.1686\end{array}$ & $\begin{array}{l}(0.0333) \\
0.0934\end{array}$ \\
\hline GDP growth & $(0.0322)$ & $(0.0254)$ & $(0.1058)$ & $(0.0577)$ \\
\hline Openness to trade & $\begin{array}{l}-0.0012 \\
(0.0060)\end{array}$ & $\begin{array}{l}-0.0010 \\
(0.0030)\end{array}$ & $\begin{array}{l}-0.0012 \\
(0.0462)\end{array}$ & $\begin{array}{l}0.0177 \\
(0.0135)\end{array}$ \\
\hline $\begin{array}{l}\text { Political stability \& } \\
\text { Absence of } \\
\text { violence }\end{array}$ & $\begin{array}{l}-0.0260 \\
(0.0161)\end{array}$ & $\begin{array}{l}-0.0068 \\
(0.0074)\end{array}$ & $\begin{array}{l}-0.0058 \\
(0.0119)\end{array}$ & $\begin{array}{l}-0.0374 * \\
(0.0192)\end{array}$ \\
\hline Total taxation & -0.0014 & 0.0011 & -0.0019 & $0.0327^{*}$ \\
\hline Total taxalloni & $(0.0133)$ & $(0.0164)$ & $(0.0205)$ & $(0.0175)$ \\
\hline Constant & $\begin{array}{l}29.3958 \\
(3.3848)\end{array}$ & & & $\begin{array}{l}31.7786^{* * *} \\
(4.5076)\end{array}$ \\
\hline Year 2005 & - & - & - & $\begin{array}{l}1.1407 * * \\
05803)\end{array}$ \\
\hline Year 2006 & $\begin{array}{l}0.3947 * * * \\
01478)\end{array}$ & - & $\begin{array}{l}0.4955^{* *} \\
(0.2406)\end{array}$ & $\begin{array}{l}1.5022 * * * \\
(0.5298)\end{array}$ \\
\hline Year 2007 & $\begin{array}{l}(0.14 / 8) \\
0.7877 * * *\end{array}$ & & $\begin{array}{l}(0.2400) \\
1.0350^{* * *}\end{array}$ & $\begin{array}{l}(0.7298) \\
1.7614 * * *\end{array}$ \\
\hline & $(0.1548)$ & - & $(0.3767)$ & $(0.4383)$ \\
\hline Year 2008 & $0.7699 * * *$ & - & $1.3875^{*}$ & $\begin{array}{l}1.7999 * * * \\
(0.4795)\end{array}$ \\
\hline & $(0.2335)$ & & $\begin{array}{l}(0.7700) \\
1.2227\end{array}$ & $\begin{array}{l}(0.4795) \\
1.0288 *\end{array}$ \\
\hline Year 2009 & $\begin{array}{l}-0.0749 \\
(0.5250)\end{array}$ & - & $\begin{array}{l}1.2227 \\
(0.9477)\end{array}$ & $\begin{array}{l}1.0200 \\
(0.55209)\end{array}$ \\
\hline Year 2010 & $\begin{array}{l}-0.0305 \\
(0.3974)\end{array}$ & - & $\begin{array}{l}0.2569 \\
(0.7792)\end{array}$ & $\begin{array}{l}0.4948 \\
(0.4286)\end{array}$ \\
\hline
\end{tabular}


EMMANOUILIDIS AND KARPETIS Entry Regulation and FDI

Table 2 continued

\begin{tabular}{|l||l|l|l|l|}
\hline \multicolumn{1}{|l||}{ Variables } & \multicolumn{3}{|c|}{ High income } \\
\hline & $\begin{array}{c}\text { Fixed } \\
\text { Effects }\end{array}$ & $\begin{array}{c}\text { Bootstrap } \\
\text { Fixed } \\
\text { Effects }\end{array}$ & $\begin{array}{l}\text { Difference } \\
\text { GMM }\end{array}$ & $\begin{array}{c}\text { System } \\
\text { GMM }\end{array}$ \\
\hline Year 2011 & -0.2643 & - & 0.4949 & 0.3563 \\
Year 2012 & $(0.6575)$ & & $(1.2577)$ & $(0.5179)$ \\
Year 2013 & 0.1253 & - & 0.7655 & 0.3996 \\
& $(0.4365)$ & & $(1.3760)$ & $(0.4012)$ \\
Year 2014 & -0.4851 & - & 0.2443 & 0.0126 \\
& $(0.7143)$ & & $(1.4758)$ & $(0.5252)$ \\
Year 2015 & 0.0039 & - & 0.2959 & 0.1070 \\
& $(0.4409)$ & & $(1.4798)$ & $(0.3865)$ \\
Year 2016 & -0.0443 & - & 0.0494 & - \\
& $(0.3941)$ & & $(1.0844)$ & 0.2565 \\
Year 2017 & 0.1272 & - & 0.2558 & $(0.2486)$ \\
Number of obs. & $(0.3860)$ & & $(1.0073)$ & -2.0487 \\
$\mathrm{R}^{2}$ within & -1.5657 & - & -0.1324 & $(1.5278)$ \\
Instruments & $(1.2713)$ & - & $(1.0929)$ & 532 \\
AR(1) & 532 & 496 & 463 & - \\
AR(2) & -.1181 & - & - & 41 \\
Overidentification & - & - & 37 & 0.008 \\
Test & - & - & 0.013 & 0.342 \\
\hline
\end{tabular}

Note: $*, * *, * * *$ denote significance at 10,5 and $1 \%$ levels of significance, respectively. Standard errors, which are presented in parentheses, are robust in the presence of any pattern of autocorrelation and heteroskedasticity.

inflow of FDI in logarithmic terms has an upward trend in Low \& Lower-middle income countries, contrary to the other income groups in which foreign investment did not change significantly. Of course, a factor that might have influenced the time-path of foreign investment is the economic crisis, the effects of which are more pronounced in High-income countries.

The resulted estimates for each one of the three income groups are shown in Table 2. As it was expected, the factors that can influence countries' level of FDI vary across different income groups. The only exemption for which there is no important difference across the various estimators and income groups in terms of statistical significance is the Lagged FDI. The fact that the latter is statistically significant in most cases confirms the dynamic nature of FDI and implies that the prior level of foreign capital poured into a specific economy is capable of affecting the decisions on FDI location irrespective of countries' level of income. However, the sign of the effect is not identical across the three income groups as in the High- 
income the Lagged FDI is negatively associated with its current-period level, probably as a consequence of the economic crisis.

It should be also noted that in the case of Low \& Lower-Middle and Upper-Middle income groups, the autoregressive coefficient values of the first difference GMM lie below the corresponding value of the FE estimator. This could be an indication of possible existence of bias due to weak instruments.

Another interesting conclusion regarding the results of Table 2 is drawn from the variable of Entry barriers. Based on the estimated coefficients of that variable, it is obvious that although the sign of the impact is negative in all cases, there are a few differences in terms of statistical significance. In particular, the results show a statistically significant relationship between the variables under examination in the Low \& Lower-middle and Upper-middle income countries, but mainly when the Bootstrap FE is employed. On the contrary, the estimates associated with the High-income group do not reveal a statistically significant effect of the index on FDI, at least at a 5\% significance level. The presence of a statistically significant relationship between barriers to entry and FDI in at least one estimator in the first two income groups could be attributed to, as it was above-mentioned, the high degree of business regulation that those countries impose on prospective investors. Although there is no strong indication, our results could probably imply that entry regulation is a limiting factor in FDI attraction only when countries regulate their markets heavily.

Concerning the magnitude of the impact, it is obvious that this is higher than that of the aggregate estimates as the significant coefficient values now range, in absolute terms, from 0.0068 to 0.0098 . This means that an increase in barriers to entry will result in higher percentage changes in the inflow of FDI. More specifically, a unit increase (decrease) of Entry barriers would lead to a $0.68 \%$ and $0.98 \%$ decrease (increase) of inward FDI in the Low \& Lower-middle and Upper-middle income group, respectively.

Turning to the rest explanatory variables, GDP growth plays a critical role in FDI attraction in all income groups. Nevertheless, a statistical significant relationship with the dependent variable arises mainly in the FE-type estimators. The only exception is the difference GMM estimates related to the Low \& Lower-middle income countries, where the sign of the effect in this case, although statistically significant, is negative. The negative connection between GDP growth and FDI could emerge due to various reasons. First, during a recession host countries may be more attractive to a specific type of FDI. For example, merger and acquisitions, through which investors can push labor and capital cost downwards, may be more intense over a period of recession. Second, in countries where there is underemployment of relatively cheap capital and labor, there can be an opportunity for future profits from the unused resources (Iamsiraroj and Doucouliagos, 2015). In both cases, therefore, low economic performance could be related to high inflows of FDI. On the contrary, a positive and statistically significant relationship implies that market growth 


\section{EMMANOUILIDIS AND KARPETIS Entry Regulation and FDI}

prospects are of particular interest as fast growing economies offer a signal of profitable investments.

As regards the effects of the variable of Inflation, there is an indication of a positive impact on FDI when focusing on Low \& Lower-middle and Upper-middle income countries. In spite of being a signal of economic uncertainty, Inflation, as discussed above, can also be useful in reducing the rigidity of nominal prices and wages. Such a positive and statistically significant relationship of Inflation with the level of FDI is in line with the one observed in the difference GMM of the aggregate estimates. On the other hand, the results in Highincome countries reveal no connection between Inflation and FDI. This suggests, therefore, that even an effective Inflation targeting is not capable of attracting FDI.

Moreover, the results regarding the sign of the variable of Openness to trade suggest a positive connection with inward FDI in the groups of Low \& Lower-middle and Uppermiddle income and mainly negative when the sample consists of High-income countries. Nevertheless, the relationship between Trade openness and FDI is in general insignificant, with the exception of Low \& Lower-middle income countries where a weak evidence of significance is found. For this specific income group, therefore, foreign investors apart from the entry regulatory climate are probably interested in the access to foreign markets through international trade.

Furthermore, the magnitude of a country's Political stability and Absence of violence is still not found relevant to the inflow of FDI in the majority of the derived estimates albeit the weak evidence of statistical significance that is observed in the context of the system GMM estimations. Thus, the estimates related to Political stability and Absence of violence suggest in general that the extent to which countries experience political instability and politically motivated violence is rather not associated with investment decisions.

Also, the results related to Total taxation indicate, in general, negative effects on the inflow of FDI. Nevertheless, such impact is insignificant in the majority of the employed estimators irrespective of the income group. This result is of course consistent with the estimates of the previous section implying that investors do not react to corporate taxation when they take decisions on FDI location.

Finally, although significance arises mainly in the case of the FE estimator the estimated coefficients of time-period effects generally indicate a positive relationship with FDI for the Low \& Lower-middle income group. In terms of the magnitude of the effect, the average annual impact on FDI in the case of the FE estimator equals 55.29\% during the period from 2007 to 2017. Similarly, the results for the Upper-middle income group reveal a positive effect on FDI, which is mainly statistically significant in the FE and system-GMM estimator. Moreover, in the first years of the sample period the derived coefficients for the High-income group indicate a positive and statistically significant relationship with FDI, which is, however, interrupted after the outbreak of the economic crisis, namely after the year 2008. 


\section{Conclusions}

Aiming to increase entrepreneurship and job creation by improving the investment climate, a growing number of countries is implementing reforms in the areas measured by Doing Business. Focusing on entry regulation the objective of this paper was to investigate whether regulatory reforms on this area are capable of affecting the level of inward FDI. The empirical evidence from the various dynamic estimators revealed a negative association between Entry barriers and FDI inflows. This negative association was statistically significant in the case of the Bootstrap FE, at all levels of significance, and in the FE and system GMM estimators, at a $10 \%$ significance level.

When focusing on different data classifications based on countries' level of income the existence of a negative and statistically significant relationship between the two variables was again confirmed mainly by the bootstrap FE estimator, but now only for the groups of Low \& Lower-middle and Upper-middle income. Our results, therefore, indicate that the negative and statistically significant outcome found in the full sample was mainly due to the relationship in the two above income groups. This is not surprising given the relatively high entry barriers imposed by the governments of these countries. Thus, despite the efforts of reducing entry barriers from the majority of Low and Middle income countries, further improvements in the entry regulatory environment that reduce the procedures, costs and days for a new business to start would be beneficial for foreign investors. On the contrary, the level of FDI seems to be insensitive to any reduction of Entry Barriers in the countries of High-income.

Moreover, the estimates of section 5 give rise to another interesting implication. Although there is no strong evidence, the fact that significance between entry regulation and FDI arises only in countries with relatively high entry barriers could be an indication of a non-linear association in the sense that the effects of Entry barriers may be negative only after a specific threshold has been reached. Thus, for future research the investigation of non-linearities in the relationship between Entry barriers and FDI would be of particular interest. This would help the specialization of more effective policies with regard to entry regulation as governments will acquire knowledge as to what extent they should regulate their markets.

Finally, as more data from the Doing Business become available over time, it will be possible to employ panel data with a large time dimension. This will enable researchers to examine, firstly, the existence of a long-run stable relationship between the measures of Doing Business and FDI, and secondly, the short-run effects and the possibility of reverse causality, by using panel cointegration and causality methods, respectively. The availability of longer time series will also allow the exploitation of heterogeneous estimators in the relative literature such as the Mean Group estimator of Pesaran and Smith (1995), which uses the mean of unit estimates and produces consistent parameter estimates when heterogeneity exists. 


\section{EMMANOUILIDIS AND KARPETIS Entry Regulation and FDI}

\section{References}

Adams, S. (2009). Foreign Direct investment, domestic investment, and economic growth in Sub-Saharan Africa. Journal of Policy Modeling, 31(6), 939-949.

Alesina, A., Ardagna, S., Nicoletti, G., \& Schiantarelli, F. (2005). Regulation and investment. Journal of the European Economic Association, 3(4), 791-825.

Alfaro, L., A. Chanda, S. Kalemli-Ozcan, and Sayek S. (2010). Does Foreign Direct Investment Promote Growth? Exploring the Role of Financial Markets on Linkages. Journal of Development Economics, 91(2), 242-256.

Alfaro, L. (2003). Foreign Direct Investment and Growth: Does the Sector Matter? Harvard Business School Working Paper.

Arellano, M., Bond, S. (1991). Some tests of specification for panel data: Monte Carlo evidence and an application to employment equations. The Review of Economic Studies, 58(2), 277-297.

Arbatli, E. C. (2011). Economic Policies and FDI Inflows to Emerging Market Economies. working paper 11-192, International Monetary Fund, Washington, DC.

Asiedu, E. (2006). Foreign direct investment in Africa: The role of natural resources, market size, government policy, institutions and political instability. The World Economy, 29(1), 63-77.

Barseghyan, L. (2008). Entry costs and cross-country differences in productivity and output. Journal of Economic Growth, 13(2), 145-167.

Basu, P., Guariglia, A. (2007). Foreign Direct Investment, inequality, and growth. Journal of Macroeconomics, 29(4), 824-839.

Bayraktar, N. (2015). Importance of Investment Climates for Inflows of Foreign Direct Investment in Developing Countries. Business and Economic Research, 5(1), 24-50.

Bénassy-Quéré, A., Fontagné, L., \& Lahrèche-Révil, A. (2005). How does FDI react to corporate taxation?. International Tax and Public Finance, 12(5), 583-603.

Bloningen, B.A. (2005). A Review of the Empirical Literature on FDI Determinants. Atlantic Economic Journal, 33(4), 383-403.

Bobenič-Hintošová, A., Kubíková, Z., Ručinský, R. (2016). Does quality of business environment influenc Foreign Direct Investment? A case of Central European countries. Central European Journal of Management, 3(1).

Bond, S., Hoeffler, A., \& Temple, J. (2001). GMM estimation of empirical growth models. No 2001-W21.Economics Group, Nuffield College, University of Oxford.

Branstetter, L., Lima, F., Taylor, L. J., Venâncio, A. (2014). Do entry regulations deter entrepreneurship and job creation? Evidence from recent reforms in Portugal. The Economic Journal, 124(577), 805-832. 
Busse, M., Groizard, J.L. (2008). Foreign Direct Investment, Regulations and Growth. The World Economy, 31(7), 861-86.

Card, D., \& Hyslop, D. (1997). Does inflation" grease the wheels of the labor market"?. In Reducing inflation: Motivation and strategy (pp. 71-122). University of Chicago Press.

Crespo, N., Fontoura, M. P. (2007). Determinant factors of FDI spillovers-what do we really know?. World Development, 35(3), 410-425.

Corcoran, A., Gillanders, R. (2015). Foreign direct investment and the ease of doing business. Review of World Economics, 151(1), 103-126.

Da Rin, M., Di Giacomo, M., Sembenelli, A. (2011). Entrepreneurship, firm entry, and the taxation of corporate income: Evidence from Europe. Journal of Public Economics, 95(9), 1048-1066.

De Vos, I., Everaert, G., Ruyssen, I. (2015). Bootstrap-based bias correction and inference for dynamic panels with fixed effects. Stata Journal (forthcoming), 1-31.

Dhakal, D., Rahman, S., Upadhyaya, K. P. (2007). Foreign direct investment and economic growth in Asia. Indian Journal of Economics and Business, 6(1), 15-26.

Djankov, S., La Porta, R., Lopez-de-Silanes, F., Shleifer, A. (2002). The regulation of entry. The Quarterly Journal of Economics, 117(1), 1-37.

Economou, F., Hassapis, C., Philippas, N., \& Tsionas, M. (2017). Foreign direct investment determinants in OECD and developing countries. Review of Development Economics, 21(3), 527-542.

Eicher, T. S., Helfman, L., Lenkoski, A. (2012). Robust FDI determinants: Bayesian model averaging in the presence of selection bias. Journal of Macroeconomics, 34(3), 637-651.

Gastanaga, V., Nugent, J., Pashamova, B. (1998). Host country reforms and FDI inflows: How much difference do they make? World Development, 26(7), 1299-1314.

Graham, E. M., \& Krugman, P. R. (1989). Foreign direct investment in the United States. Institute for International Economics, Washington, DC, 65-93.

Hossain, M. T., Hassan, Z., Shafiq, S., \& Basit, A. (2018). Ease of Doing Business and Its Impact on Inward FDI. Indonesian Journal of Management and Business Economics, 1(1), $52-65$.

Iamsiraroj, S., \& Doucouliagos, H. (2015). Does growth attract FDI? Economics-The OpenAccess, Open-Assessment E-Journal, 9, 1-35.

Kaplan, D. S., Piedra, E., \& Seira, E. (2011). Entry regulation and business start-ups: Evidence from Mexico. Journal of Public Economics, 95(11-12), 1501-1515.

Khan, G. S., \& Mitra, P. (2014). A Causal Linkage between FDI Inflows with Select Macroeconomic Variables in India-An Econometric Analysis. Journal of Economics and Finance, 5(5), 124-133.

Kiviet, J. F. (1995). On bias, inconsistency, and efficiency of various estimators in dynamic panel data models. Journal of Econometrics, 68(1), 53-78. 


\section{EMMANOUILIDIS AND KARPETIS Entry Regulation and FDI}

Klapper, L., Laeven, L., Rajan, R. (2006). Entry regulation as a barrier to entrepreneurship. Journal of Financial Economics, 82(3), 591-629.

Klapper, L., \& Love, I. (2010). The impact of business environment reforms on new firm registration. The World Bank.

Krifa-Schneider, H., Matei, I. (2010). Business Climate, Political Risk and FDI in Developing Countries: Evidence from Panel Data. International Journal of Economics and Finance, (2) 5, 54-65.

Kurecic, P., \& Kokotovic, F. (2017). The Relevance of Political Stability on FDI: A VAR Analysis and ARDL Models for Selected Small, Developed, and Instability Threatened Economies. Economies, 5(3), 22.

Jayasuriya, D. (2011). Improvements in the world bank's ease of doing business rankings: Do they translate into greater foreign direct investment inflows? Policy Research Working Paper 5787, Washington, DC: World Bank.

Jovanovic, B., Jovanovic, B. (2015). Ease of doing business and FDI in the ex-socialist countries. International Economics and Economic Policy, 1-41.

Masron, T., Abdullah, H. (2010). Institutional Quality as a Determinant for FDI Inflows: Evidence from ASEAN. World Journal of Management, 2(3), 115-128.

Morisset, J. P., Lumenga-Neso, O. (2002). Administrative barriers to foreign investment in developing countries. World Bank, Policy Research Working Paper 2848, Washington, DC: World Bank.

Morris, R., Aziz, A. (2011). Ease of doing business and FDI inflow to Sub-Saharan Africa and Asian countries. Cross Cultural Management: An International Journal, 18(4), 400411.

Nickell, S. (1981). Biases in dynamic models with fixed effects. Econometrica, 49(6), 14171426.

Pesaran, M. H., \& Smith, R. (1995). Estimating long-run relationships from dynamic heterogeneous panels. Journal of Econometrics, 68(1), 79-113.

OECD (2008). Tax effects on Foreign Direct investment, Policy Brief.

Olival, A. (2012). The influence of Doing Business' Institutional Variables in Foreign Direct Investment (No. 0048). Gabinete de Estratégia e Estudos, Ministério da Economia.

Pigou, A. (1938). The Economics of Welfare, 4th edn. London: Macmillan.

Peltzman, S. (1976). Toward a more general theory of regulation. The Journal of Law and Economics, 19(2), 211-240.

Posner, R. A. (1971). Taxation by regulation. The Bell Journal of Economics and Management Science, 2(1), 22-50.

Querbach, T., C. Arndt (2017). Regulatory policy in Latin America: An analysis of the state of play. OECD Regulatory Policy Working Papers, No. 7, OECD Publishing, Paris. 
Sayek, S. (2009). Foreign direct investment and inflation. Southern Economic Journal, 76(2), 419-443.

Shahadan, F., Sarmidi, T., \& Faizi, F. J. (2014). Relationships between Doing Business Indexes and FDI Net Inflows: Empirical Evidence from Six Asian Countries (Afghanistan, Bangladesh, India, Iran, Pakistan and Sri Lanka). Prosiding Persidangan Kebangsaan Ekonomi Malaysia ke-9.

Stigler, G. (1971). The Theory of Economic Regulation. The Bell Journal of Economics and Management Science, 2(1), 3-21.

Svensson, J. (2005). Eight Questions about Corruption. Journal of Economic Perspectives, 19(3), $19-42$.

Tiwari, A. K., \& Mutascu, M. (2011). Economic growth and FDI in Asia: A panel-data approach. Economic Analysis and Policy, 41(2), 173-187.

Treisman, D. (2007). What Have We Learned about the Causes of Corruption from Ten Years of Cross-national Empirical Research? Annual Review of Political Science, 10, 211-244.

Vogiatzoglou, K. (2016). Ease of doing business and FDI inflows in ASEAN. Journal of Southeast Asian Economies (JSEAE), 33(3), 343-363.

Yu, J., \& Walsh, M. J. P. (2010). Determinants of foreign direct investment: A sectoral and institutional approach (No. 10-187). International Monetary Fund.

Windmeijer, F. (2005). A finite sample correction for the variance of linear efficient two-step GMM estimators. Journal of Econometrics, 126(1), 25-51.

Zhang, K. H. (2001). Does foreign direct investment promote economic growth? Evidence from East Asia and Latin America. Contemporary Economic Policy, 19(2), 175-185.

\section{Appendix}

Diagram 1. Scatter plot of average values of Entry Barriers and FDI inflows over the available period of each country.

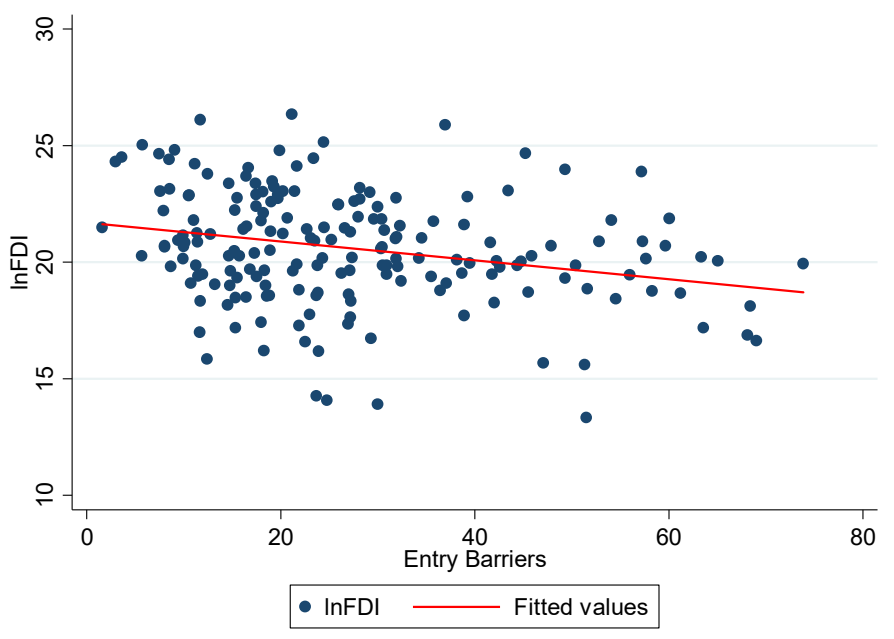




\section{EMMANOUILIDIS AND KARPETIS Entry Regulation and FDI}

Table 3. Average value of Entry Barriers and FDI according to income classification

\begin{tabular}{|c|c|c|c|c|}
\hline Income Group & \multicolumn{2}{|c|}{ Average value } & Standard error & $95 \%$ confidence interval \\
\hline \multicolumn{5}{|l|}{ Entry Barriers } \\
\hline $\begin{array}{c}\text { Low and Lower- } \\
\text { middle }\end{array}$ & 36.174 & 0.627 & 34.943 & 37.406 \\
\hline Upper-Middle & 24.680 & 0.578 & 23.544 & 25.816 \\
\hline High-income & 16.369 & 0.423 & 15.538 & 17.199 \\
\hline \multicolumn{5}{|l|}{ FDI (billion USD) } \\
\hline $\begin{array}{l}\text { Low and Lower- } \\
\text { middle }\end{array}$ & 1.248 & 0.123 & 1.006 & 1.490 \\
\hline Upper-Middle & 9.044 & 1.196 & 6.697 & 11.391 \\
\hline High-income & 28.184 & 2.495 & 23.290 & 33.078 \\
\hline
\end{tabular}

Diagram 2: Diachronic evolution of Entry Barriers (left) and FDI inflows (right) over the available period for each income group.
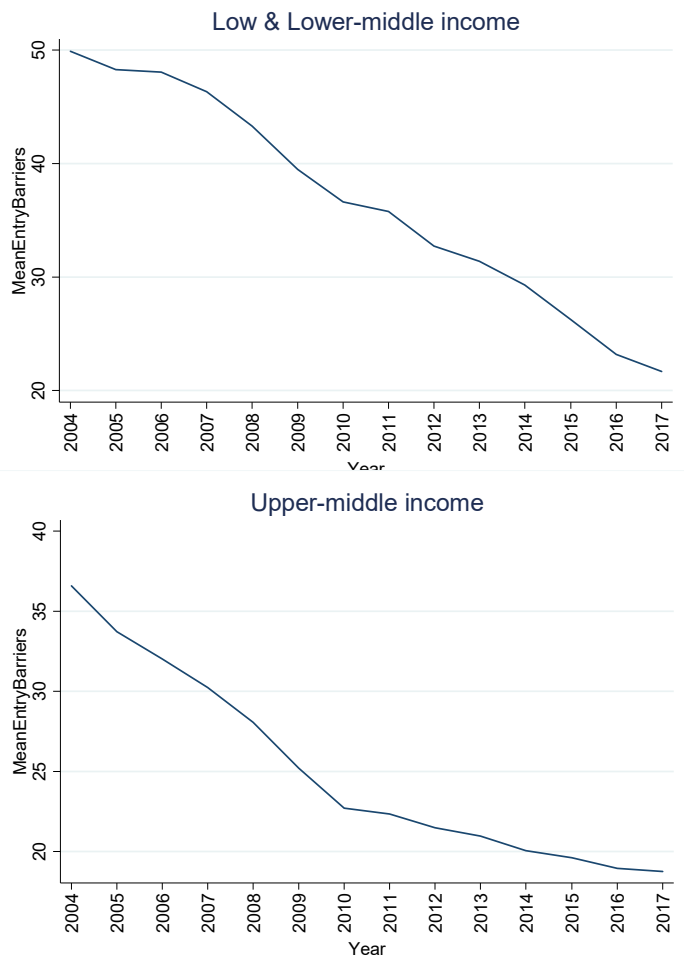
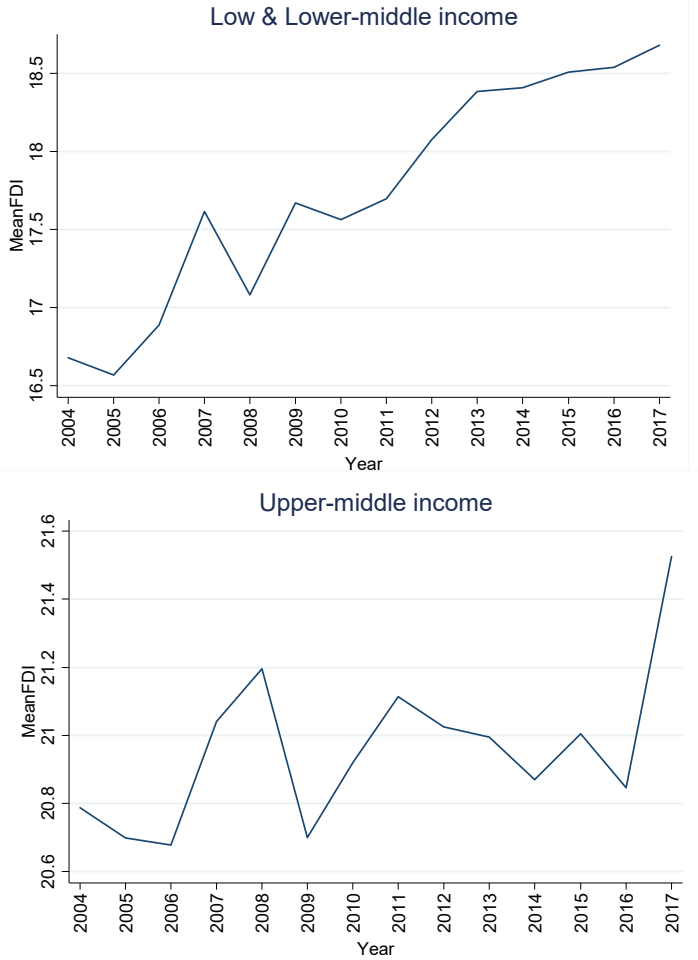
Review of Economic Analysis 11 (2019) 175-202

Diagram 2 continued
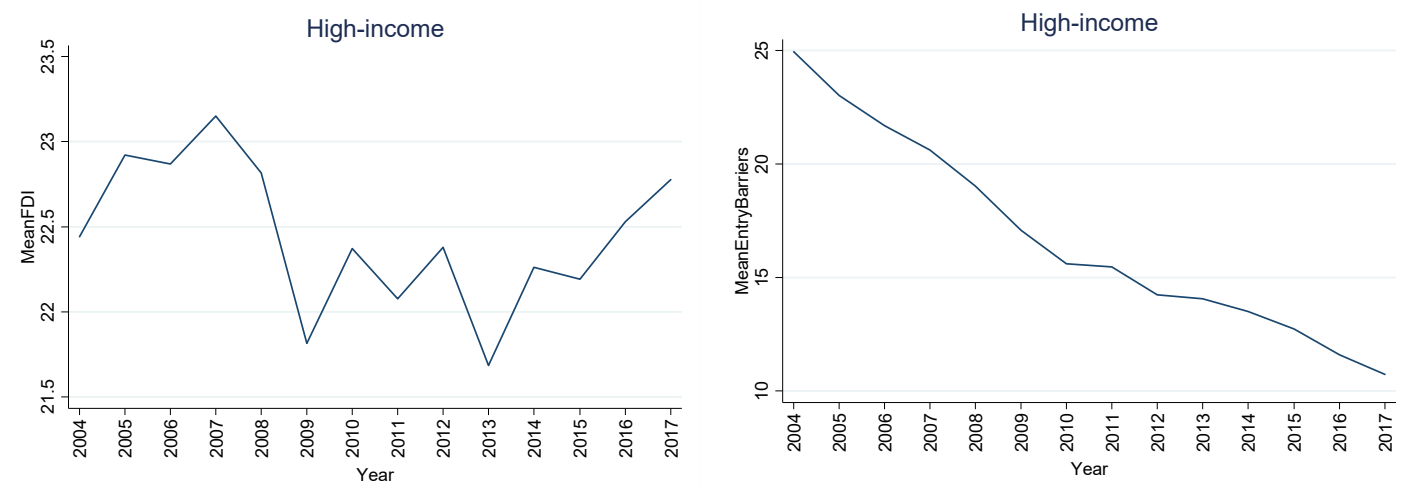